\title{
重症破裂脳動脈瘤急性期における重症度改善例の検討
}

\author{
佐藤 光夫, 児玉南海雄, 佐々木達也 \\ 鈴木 恭一，佐藤 正憲，松本 正人
}

\section{Analysis of Patients with Grade Up of Hunt and Kosnik Grade IV $\cdot V$ in the Acute Stage}

Mitsuo Sato, M.D., Namio Kodama, M.D., Tatsuya Sasaki, M.D., Kyouichi Suzuki, M.D., Masanori Sato, M.D., and Masato Matsumoto, M.D.

Department of Neurosurgery, Fukushima Medical School, Fukushima, Japan

Summary: Of patients in poor neurological condition after aneurysmal subarachnoid hemorrhage (SAH), we have often experienced cases in which grades have improved during a relatively short time after admission. In this paper, we examine changes of neurological grades on 80 patients who did not undergo urgent surgery in the acute stage of Hunt and Kosnik Grade IV and V (Grade IV 30 cases, V 50 cases).

Of the 80 patients, 27 (34\%) showed grade improvement after admission. Fifteen (50\%) were in Grade IV and 12 (24\%) in Grade V. Of the 15 patients in Grade IV, 6 improved to Grade II and 9 to Grade III within 48 hours. Of the 12 patients in Grade V, 2 improved to Grade II, 3 to Grade III, and 7 to Grade IV within 24 hours. All patients were classified as Fisher Group 3 or 4 on the CT scan. There was no relationship between Fisher group and grade improvement. The rate of improvement in 51 patients of the younger group (69 years and under) was $45 \%$, whereas that in 29 patients of the elderly group (70 years and over) was $14 \%$. Of the 27 patients whose clinical course improved, acute surgery was performed in 25 patients and chronic surgery in 2 patients. As for the outcome at discharge, 9 (60\%) in Grade IV and 6 (50\%) Grade V made a good recovery or moderate disability.

We should closely observe changes in Grade IV $\cdot V$ patients at least for 24 hours, so that we can perform surgery as soon as the patient's grade improves.

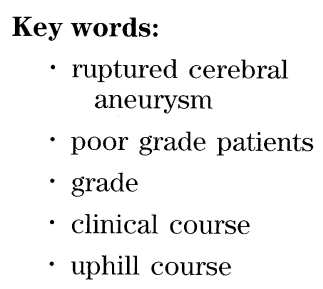

Surg Cereb Stroke (Jpn) 28: 371-374, 2000

\section{はじめに}

Hunt and Kosnik $(\mathrm{H} \& \mathrm{~K})^{6)}$ によるGrade IV・Vの重症 破裂脳動脈瘤の治療成績は依然として満足すべきものでは ない2)3(11)15)17)18)19)21).われわれはH＆ K Grade IV • $\mathrm{V}$ の重症例のなかで大きな脳内血腫, 鋳型状に充満された
脳室内出血や硬膜下血腫などが重症度に関与していると思 われる症例では，ただちにそれらの処置とともに根治術を 行う方針としている。それ以外の症例ではいったん重症度 の変化を観察し，その後の治療方針を決定しているが，こ れら経過観察例のなかには重症度が不変ないしは悪化し予 後不良となる症例群と, 徐々に状態が改善傾向を示し根治 


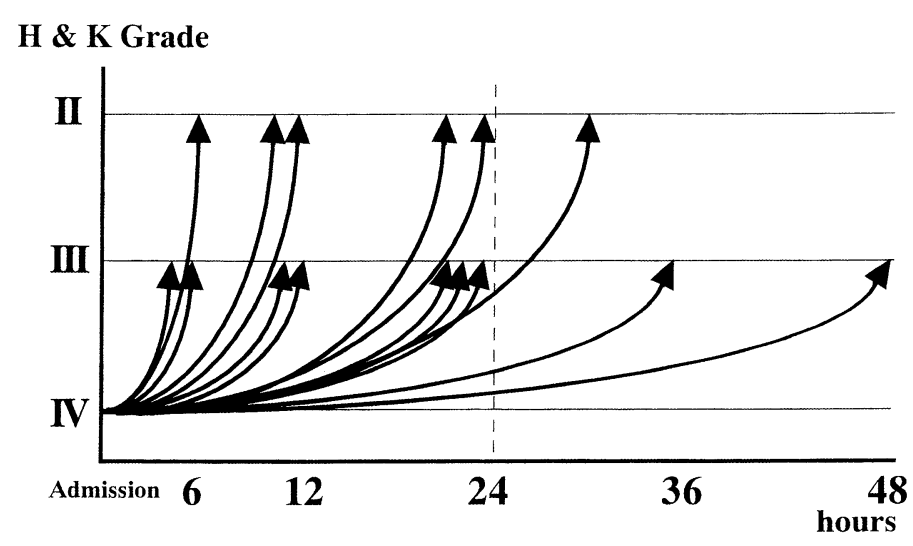

Fig. 1 Degree and time of improvement in Grade IV patients.

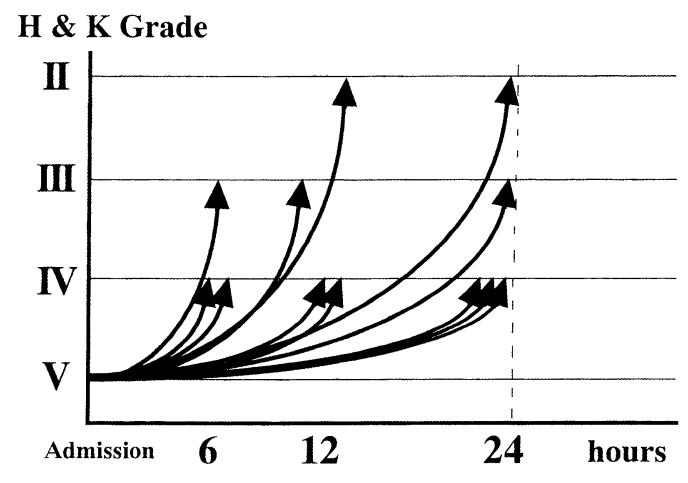

Fig. 2 Degree and time of improvement in Grade $\checkmark$ patients.

術により予後良好となる症例群とがある.

重症度が発症後比較的短時間に改善する症例が存在する ことは以前より指摘されていたが7)8)9)12)13)17)，どのくら いの期間を観察すれば状態改善を把握できるのか，はたま たどの程度まで変化しうるものなのかなどについて詳細に 検討された報告は見当たらない.今回，われわれは来院時 $\mathrm{H} \& \mathrm{~K}$ Grade IV ・Vの重症例において, これらの点を中 心に臨床像の経過を検討，考察したので報告する。

\section{対象と方法}

対象は 1983 年 4 月から 1998 年 3 月までの 15 年間に当科 で経験した破裂脳動脈瘤症例のうち，発症 6 時間以内に搬 送され, 来院時 $\mathrm{H} \& \mathrm{~K}$ Grade IV ・ Vの重症例で，かつ脳 室ドレナージや脳内血腫摘出などの緊急処置にて状態を改 善させうる要因を伴わず, 経過観察とした 80 例である. 入院時の grade はIVが 30 例, Vが 50 例で, 性別は男性 32 例，女性 48 例であった。年齢は 33-84 歳 (平均 62.2 歳) で，70歳未満が 51 例， 70 歳以上の高齢者が 29 例であっ た. 80 例中状態の悪い 14 例では脳血管撮影や 3D-CT angiographyが施行できず，残る 66 例に検査を行った。 これら 66 例の破裂脳動脈瘤の内訳は前交通動脈瘤 20 例, 内頸動脈瘤 16 例, 椎骨脳底動脈瘤 15 例, 中大脳動脈瘤 11 例そして前大脳動脈瘤 4 例であった．来院後は hypoxia を 防止するため気管内挿管を含めた十分な呼吸管理を行い, 適宜マニトールやステロイドの投与を行った。また，再破 裂予防のため収縮期血圧を 90-110 mmHg 前後とする徹底 した血圧管理 ${ }^{16)} も$ 行った。

この 80 症例について，1）重症度改善例の頻度，2）重 症度改善時期と改善度，3）重症度改善例における Fisher 分類，4）重症度改善例と年齢の相関，5）重症度改善例に 対する治療と退院時成績について検討した。

\section{1. 重症度改善例の頻度}

80 例中 27 例 (34\%) で重症度の改善が認められた。来院 時 Grade IVの 30 例中 15 例 (50\%), そしてGrade Vの 50 例中 12 例 $(24 \%)$ で改善がみられた。

\section{2. 重症度改善時期と改善度}

Grade IV の改善例 15 例 (15/30 例, 改善例 50\%)におけ る経過をみると 15 例中 12 例 $(80 \%)$ は 24 時間までに改善し ており，残る 3 例は 48 時間までに改善し，これ以降の上 昇傾向例は認められなかった。 また, Grade IIへの改善例 が6例, Grade IIIへの改善例が9例であった(Fig. 1).

次に Grade Vの改善例 12 例 (12/50 例, 改善例 $24 \%)$ を みると, 12 例全例が 24 時間以内に改善しており, これ以 降の改善例は認められなかった。 また, Grade II まで回復 したものが 2 例, Grade IIIまでが 3 例, そしてGrade IV に上昇していたものが7例であった (Fig. 2).

\section{3. 重症度改善例における Fisher 分類}

80 例の来院時 CT 所見は, Fisher 分類の Group 3 が 39 例, Group 4 が 41 例と両者の割合はほぼ同数であった. 改善例 27 例では Fisher 分類の Group 3 が 13 例, Group 4 が14例であった。

\section{4. 重症度改善例と年齢の相関}

70 歳未満の 51 例における改善例は 23 例であり, 70 歳 以上の高齢者では 29 例中改善例は 4 例であった。

\section{5. 改善例に対する治療と退院時成績}

改善例は原則として根治術を行う方針とした. 肺水腫を 
Table 1

Hunt and Kosnik Grade and outcome of Grade IV patients with grade improvement

\begin{tabular}{ccccccc}
\hline & \multicolumn{5}{c}{ Glasgow Outcome Scale } \\
\cline { 2 - 5 } Grade & GR & MD & SD & VS & D & Total \\
\hline II & 2 & 1 & 2 & 0 & 1 & 6 \\
III & 3 & 3 & 2 & 1 & 0 & 9 \\
\hline Total & 5 & 4 & 4 & 1 & 1 & 15 \\
\hline
\end{tabular}

GR: good recovery, MD: moderate disability, SD: severe disability, VS: vegetative state, D: death

きたした中大脳動脈瘤と脳底動脈瘤の各 1 例は慢性期の待 機手術としたが, 他の 25 例は 72 時間以内の急性期に根治 手術を施行した. neck clipping終了後に脳血管攣縮の発 現が危惧される症例では，術後の血腫除去を原則とした予 防法を実施した。すなわち，〈も膜下血腫や血性䯣液を排 除すべく, 25 例中 6 例で持続脳槽ドレナージを設置し, さらにウロキナーゼとアスコルビン酸による脳槽灌流療法 10)を13例で施行した.

重症度改善例 27 例の退院時成績は Glasgow Outcome Scaleにより評価した(Table 1, 2). Grade IVでは15例中 9 例 (60\%) が good recovery (GR) ないしは moderate disability (MD)であった。死亡の 1 例はVA-PICA の症例で 術後 14 日目に再出血をきたした症例である。一方， Grade Vでは 12 例中 6 例 (50\%)が GR およびMDで退院し ており，死亡例はなかった。

\section{考察}

発症 6 時間以内に頻発するとされる脳動脈瘤の再破裂の 防止を目的に積極的に早期手術を行った場合, Grade IV まれにはVでも予想外に転帚良好例が得られることがあ $ろ^{2)}$. この予想外の結果は, 発症後 2 週間を待機し, その 時点での grading で手術適応を決定していた時代の手術成 績からは想像もできないことであった。発症後 2 週間を経 た時点での Grade IV およびVの症例群では，脳の organic damageがほぼ完成し不可逆的状態となっており，手術 によって動脈瘤を処置しても患者の状態がよくならなかっ たことは先人達の成績で示されている5)。われわれはこれ らの経験を踏まえ，急性期に扔ける重症例には大きく二つ のタイプがあるのではないかと考えた。すなわち，ひとつ は発症時の一次脳損傷が高度でもはや回復することはでき ない重症例であり，他のひとつはくも膜下出血による急激 な脳圧上昇とそれに伴う広範な虚血などを含めた病態が脳 の不可逆的損傷までに至らず，回復の可能性がある場合で ある，橋本らも重症破裂脳動脈瘤治療の問題点として, 来 院時の poor gradeが永続的なものか, それとも改善しう
Table 2 Hunt and Kosnik Grade and outcome of Grade V patients with grade improvement

\begin{tabular}{ccccccc}
\hline & \multicolumn{5}{c}{ Glasgow } & Outcome Scale \\
\cline { 2 - 5 } Grade & GR & MD & SD & VS & D & Total \\
\hline II & 1 & 0 & 0 & 1 & 0 & 2 \\
III & 0 & 2 & 1 & 0 & 0 & 3 \\
IV & 1 & 2 & 2 & 2 & 0 & 7 \\
\hline Total & 2 & 4 & 3 & 3 & 0 & 12 \\
\hline
\end{tabular}

GR: good recovery, MD: moderate disability, SD: severe disability, VS: vegetative state, $D$ : death.

るものかという判断が困難であると述べている ${ }^{3)}$ ．そこで われわれはGrade IV ・Vの重症例に打いて少数ながらみ られた転帰良好例が，来院後の諸検查中もしくはその後に 状態が uphill course を呈した症例に多いことに着目し， 来院時重症例に抢ける臨床像の変化について検討した。

今回対象とした 80 例中, 27 例が改善し, うち 20 例は Grade II ない III となったことは来院時 Grade IV・V の重症例でも 24 時間以内に約 $1 / 3$ の症例で grade up L, 手術適応となる可能性を示唆していた。重症度改善までの 時間に関しては来院後 24 時間までに 24 例 (89\%) が改善し, その後の 24 時間で 3 例 (11\%) と少ない症例ではあるが, 改善していた。術前に重症であったものの再破裂を予防す べく早期に手術を施行した症例のうち，予想外の良好な成 績が得られた症例がまれに存在したことは前述したが，こ れらはもし 24 時間位経過を観察していたらおそらく gradingが1-2段階上昇していた症例群であったことが考えら れた. uphill courseではあったものの gradeの上昇をみき わめる前に手術を施行したために，結果が予想外に良好と いう印象を受けたものと思われた。

以上の結果から，超急性期に搬入された重症例であって も, 24 時間以内に重症度が改善し, その後の積極的な治 療により良好な予後が期待できる症例が少なからず存在す ることが明らかとなった．したがって，重症例では再出血 の予防や脳圧を十分コントロールしながら経過を観察し， 状態が uphill courseをたどるようであれば手術適応にな るものと考える.

ところで，重症例に扔ける手術適応は以前から来院時の CT 所見や短潜時体性感覚誘発電位 (SSEP) などの電気生 理学的手法によっても検討されてきた。 CT所見としては 重症例では脳幹周囲の血腫が厚い症例が多く, 血腫そのも のによる直接的な脳幹圧迫が重症度悪化の原因の一つとさ れ, 逆に来院時重症例であっても脳幹周囲脳槽の血腫が少 ない症例では重症度の改善が期待しうるとする報告 ${ }^{13)}$ が みられる.SSEPでN16波が正常な症例 ${ }^{13)}$ やN14-N20の central conduction timeが両側正常, あるいは少なくとも 
一側が 2SD 以内であれば積極的に早期手術を行うべきと する意見 ${ }^{4)}$ みられる.

重症破裂脳動脈瘤の手術適応を決定するさいには重症度 の判定時期の問題とともに重症度の判定方法自体にも問題 がある。現在まで数多くの grading scaleが提唱されてい るが(5)6)1420)，今回われわれはH \& K の分類を用いた。 これは 1968 年にHunt \& Hessの分類として発表され ${ }^{5)}$, 1974 年に改訂されたが6)，これは発症 2 週間以降の慢性期 手術を行っていた時代に作製されたものである．初回出血 による一次脳損傷や水頭症, 脳浮腫, 脳血管攣縮などの二 次脳損傷の程度が十分把握可能な慢性期において手術が可 能か否かを判定する指標であり，これを急性期手術例の評 価に用いること自体無理が生じているものと考えられる. また，1988年には意識障害の分類法である Glasgow Coma Scaleをもとに神経脱落症状を加味した世界脳神経 外科連合分類 (WFNS 分類) ${ }^{20)}$ が発表されたが，これも慢 性期手術を想定して作成されており，Grade IV およびV と診断された症例のなかに転帰良好例が $30 \%$ 前後とかな

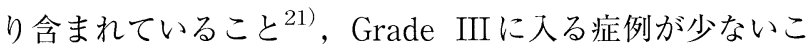
と, Grade II と III では予後に有意な差が認められない ${ }^{14)}$ といった問題点が指摘されており，この分類でも重症例の 手術適応を決定することには無理があるとされている ${ }^{22)}$. 現在破裂脳動脈溜に対しては急性期手術が一般化している ばかりでなく，今後血管内手術が普及することが予想され ることから，急性期治療を前提とした新たな重症度分類の 作成が是非必要と考えられる。

\section{結 論}

1. 来院時重症で手術適応外であった 80 例のくも膜下出血 症例群に対し経過観察を施行した結果，約 $1 / 3$ の症例 で状態が改善し手術適応となった。

2. 発症後急性期に重症 (Grade IV ・ V ) と思われるくも膜 下出血症例の状態は，必ずしも脳の organic damage を表現するものでなく，改善しうる可能性がある.

3. 発症後急性期に Grade IV ・ V の症例に対しては, 24 時間までは経過を観察し， uphill courseであれば，手 術適応となる可能性がある。ただし, Grade Vの症例 では Grade IV 以上に改善した時点で手術を考慮すべ きである。

\section{文献}

1) Botterell EH, Lougheed WM, Scott JW, et al: Hypothermia, and interruption of carotid, or carotid and vertebral circulation in the surgical management of intracranial aneurysms. J Neurosurg 13: 1-42, 1956

2) Duke BJ, Kindt GW, Breeze RE: Outcome after urgent surgery for grade IV subarachnoid hemorrhage. Surg
Neurol 50: 169-173, 1998

3）橋本信夫, 塚原徹也, 後藤泰伸, ほか: 重症破裂脳動脈瘤 の治療. 脳卒中の外科 23: 275-277, 1995

4）平林秀裕, 井上正純, 奥村嘉也, ほか: 重症破裂脳動脈瘤 における手術適応について一体性感覚誘発電位および聴性 脳幹反応による検討一. 脳卒中の外科 24: 93-100, 1996

5) Hunt WE, Hess RM: Surgical risk as related to time of intervention in the repair of intracranial aneurysms. J Neurosurg 28: 14-20, 1968

6) Hunt WE, Kosnik EJ: Timing and perioperative care in intracranial aneurysm surgery. Clin Neurosurg 21: 79-89, 1974

7）池田幸穂, 諌山和男, 矢嶋浩三, ほか：重症クモ膜下出血 超早期の病態と管理. 第 14 回日本脳卒中の外科研究会講演 集，にゅーろん社，東京，1985，pp115-119

8）加藤庸子, 佐野公俊, 金岡成益, ほか：破裂動脈瘤重症例 における治療方針の検討．脳卒中の外科 17: 219-224, 1989

9）北原孝雄, 斎藤元良, 大和田隆, ほか：脳動脈瘤根治手術 に至らず死亡したクモ膜下出血例の検討. 脳卒中の外科 $\mathbf{1 7}$ : 128-131, 1989

10) Kodama N, Sasaki T, Kawakami M, et al: Cisternal irrigation therapy with urokinase and ascorbic acid for prevention of vasospasm following aneurysmal subarachnoid hemorrhage: outcome in 217 patients. Surg Neurol 53: 110-118, 2000

11) Le Roux PD, Elliott JP, Grady MS, et al: Predicting outcome in poor-grade patients with subarachnoid hemorrhage: a retrospective review of 159 aggressively managed cases. J Neurosurg 85: 39-49, 1996

12）宮上光祐, 櫛 英彦, 菅原武仁, ほか：発症 1 時間以内に 搬入された重症破裂脳動脈瘤の病態一死亡群と生存群につ いて一．脳卒中の外科 17: 151-156, 1989

13）水野 誠, 安井信之, 鈴木明文, ほか: 強度なクモ膜下出 血による重症破裂脳動脈瘤の臨床経過. 脳神経外科 20: $21-$ 29, 1992

14）中込忠好, 高木 清, 田村 晃：〈も膜下出血の重症度分 類とその問題点. Clin Neurosci 17: 638-640, 1999

15) Rordorf G, Ogilvy CS, Gress DR, et al: Patients in poor neurological condition after subarachnoid hemorrhage: early management and long-term outcome. Acta Neurochir (Wien) 139: 1143-1151, 1997

16）佐々木達也, 藤田隆史, 児玉南海雄, ほか: 脳動脈瘤再破 裂例の検討一特に急性期の血圧管理について一. 脳卒中 12 : 237-241, 1990

17）佐藤 章：重症くも膜下出血急性期の病態と治療. 脳外誌 7: 24-31, 1998

18) Seifert V, Trost HA, Stolke D: Management morbidity and mortality in grade IV and $\mathrm{V}$ patients with aneurysmal subarachnoid haemorrhage. Acta Neurochir (Wien) 103: 5-10, 1990

19) Spetzger U, Gilsbach JM: Results of early aneurysm surgery in poor-grade patients. Neurol Res 16: 27-30, 1994

20) Teasdale GM, Drake CG, Hunt W, et al: A universal subarachnoid haemorrhage scale: report of a committee of the World Federation of Neurosurgical Societies. J Neurol Neurosurg Psychiatry 51: 1457, 1988

21）安井信之: 脳動脈瘤重症例の治療方針と outcome. 脳外誌 4: 225-231, 1995

22）吉田憲司, 中村三郎, 坪川孝志, ほか：重症破裂脳動脈瘤 早期手術に抢ける世界脳神経外科連合分類 (W.F.N.S. grading)の評価. 脳卒中の外科 17: 392-396, 1989 